\title{
Logging impact on Amazonian white-sand forests: perspectives from a sustainable development reserve
}

\author{
Layon Oreste DEMARCHI ${ }^{1,2 *} \bullet$, Veridiana Vizoni SCUDELLER ${ }^{3}$, Livia Carvalho MOURA ${ }^{4}$, Aline LOPES ${ }^{2,4}$, \\ Maria Teresa Fernandez PIEDADE ${ }^{1,2}$ \\ 1 Instituto Nacional de Pesquisas da Amazônia - INPA, Programa de Pós-Graduação em Ciências Biológicas (Botânica), Av. André Araújo 2936, Aleixo, Manaus - AM, Brasil \\ 2 Instituto Nacional de Pesquisas da Amazônia - INPA, Grupo de Ecologia, Monitoramento e Uso Sustentável de Áreas Úmidas - MAUA, Av. André Araújo 2936, Aleixo, \\ Manaus - AM, Brasil \\ 3 Universidade Federal do Amazonas - UFAM, Instituto de Ciências Biológicas - ICB, Av. General Rodrigo Otávio Jordão Ramos 3000, Aleixo, Manaus - AM, Brasil \\ ${ }^{4}$ Universidade de Brasília - UnB, Departamento de Ecologia, Campus Darcy Ribeiro, Asa Norte, Brasília - DF, Brasil \\ * Corresponding author: layon.lod@gmail.com; (D) https://orcid.org/0000-0001-8441-2106
}

\section{ABSTRACT}

Overexploitation is one of the main causes of biodiversity loss and local extinction. In the Brazilian Amazon, the intensive use of high-value timber species is leading to a decline in their populations. When in decline, these species can be replaced by less valuable and more common ones that are more feasible to exploit. We conducted interviews with residents of two communities in a sustainable development reserve in central Amazonia, and used free lists and the cognitive salience index (S) to assess the perceptions of residents regarding the occurrence and purpose of timber exploitation, and to identify possible endangered species in white-sand and terra-firme forests. In addition, to infer possible consequences of logging, we assessed the current population status of timber species cited by residents in forest-plot inventories carried out within the reserve. S-index values and interviewee reports suggested an intensive use of terra-firme timber species and an apparently recent increase in the exploitation of white-sand species, which did not use to be exploited because of their relatively low commercial value. The inventories showed that the white-sand timber species have high relative densities and low $S$ values in contrast to the terra-firme species, which mostly have low relative densities and high $S$ values. Our results highlight the need to identify and monitor relevant timber species in both terra-firme and white-sand forests, and to increase the involvement of the local community in the development of logging management practices.

KEYWORDS: cognitive salience index, timber species, tropical forest, oligotrophic ecosystem, Tupé Sustainable Development Reserve, Mezilaurus itauba

\section{O impacto madeireiro sobre as campinaranas da Amazônia: perspectivas de uma reserva de desenvolvimento sustentável}

\section{RESUMO}

A super-exploração madeireira é uma das principais causas de perda da biodiversidade e extinçôes locais. Na Amazônia brasileira o uso intensivo focado em poucas espécies tem levado à redução de suas populaçóes e à substituiçáo destas espécies, consideradas "nobres" pelo mercado madeireiro, por espécies "menos nobres" com populaçóes ainda viáveis para exploração. Nós realizamos entrevistas com moradores de duas comunidades em uma reserva de desenvolvimento sustentável na Amazônia Central, e usamos listas livres e o Índice de Saliência Cognitiva (S) para elucidar percepçôes dos moradores sobre a exploração madeireira local e identificar possíveis espécies em risco em florestas de campinarana e terra-firme. Além disso, para inferir possíveis consequências da atividade madeireira, avaliamos o atual status populacional das espécies madeireiras citadas pelos moradores em inventários florestais realizados dentro da reserva. Os resultados do $\mathrm{S}$ e os relatos dos moradores sugerem o uso intensivo de espécies madeireiras de terra-firme e um aumento aparentemente recente da exploração de espécies de campinarana, antes desprezadas pelo baixo valor comercial. Os inventários mostram que espécies madeireiras de campinarana têm altas densidades relativas e baixos valores de $S$, em contraste com espécies de terra-firme, que, em sua maioria, apresentam baixas densidades relativas e altos valores de $S$. Nossos resultados ressaltam a necessidade de identificar e monitorar as populaçóes de espécies madeireiras importantes, tanto em florestas de terra-firme quanto em campinaranas, e de involver os comunitários no desenvolvimento de políticas de manejo da exploração madeireira na reserva.

PALAVRAS-CHAVE: índice de saliência cognitiva, espécies madeireiras, floresta tropical, ecossistema oligotrófico, RDS Tupé, Mezilaurus itauba 


\section{INTRODUCTION}

The knowledge of indigenous and traditional human populations about the environment in which they live is strongly based on the perceptions gathered during day-to-day activities (Berkes et al. 2000). Since those peoples have a widely knowledge about fauna and flora, accessing this knowledge and perceptions can constitute an important tool for developing management and conservation strategies (Berkes 2004). In the Amazon, wood is one of the most common and important products derived from the forest (Galeano 2000). Usually indigenous and traditional populations practice low-impact selective logging to meet their basic needs such as building houses, boats and fences, among other uses (Lawrence et al. 2005).

The logging activity in the Amazon Basin has been concentrated along the larger rivers, specially due to easy access and timber transportation (Veríssimo et al. 1992; Wittmann and Wittmann 2010). However, with the opening of many access roads, logging activities have expanded to larger inland areas, reaching upland (terra-firme) forests distant from major rivers (Asner et al. 2005). The accessibility allowed by roads, associated with the increase of urban populations, the growing demand to supply markets in other regions, and the exploitation focused on few forest species, is leading to a drastic population decline of some Amazonian timber species in terra-firme forest, such as mahogany, Swietenia macrophylla King (known in Brazil as mogno), and Mezilaurus itauba (Meisn.) Taub. ex Mez (itaúba) (Veríssimo et al. 1995; Martinelli and Moraes 2013).

When a species shows great population decline due to overexploitation, it may be substituted by other timber species that are still commercially exploitable. This process is well described for white-water floodplain (várzea) forests, where populations of many species, such as Platymiscium pinnatum var. ulei (Harms) Klitg. (macacaúba) and Cedrela odorata L. (cedro), which are among the main targets of the timber industry, were replaced by other species, such as Ocotea cymbarum Kunth (louro-inhamui) and Calycophyllum spruceanum (Benth.) K.Schum. (pau-mulato) (Wittmann and Wittmann 2010; Fortini and Zarin 2011).

White-sand forests (known in Brazil as campinarana) grow on extremely oligotrophic sandy soils (Luizão et al. 2007). Compared with other Amazonian forest types, tree communities in campinaranas have low species diversity, usually dominated by few specialist endemic species (Fine et al. 2010; Stropp et al. 2011; Guevara et al. 2016). Campinaranas are vulnerable environments, with low productivity and low resilience to disturbance (Anderson 1981; Adeney et al. 2016), and are already undergoing several anthropic pressures, specially in the surroundings of large urban centers, including wildfires, mining for sand extraction, deforestation for cattle raising and agriculture (Ferreira et al. 2013; Adeney et al. 2016). Many trees in campinaranas are characterized by scleromorphic aspects, tortuous trunks, and low height and diameter (Anderson 1981). Therefore, they are usually considered little attractive for timber exploitation when compared to trees in other Amazonian várzea and terra-firme forests.

Despite the lower commercial value of campinarana trees, logging has been reported as a risk to these environments (Demarchi 2014; Adeney et al. 2016; Daly et al. 2016). To document this activity, we investigated the use of tree species in a sustainable development reserve (SDR) in central Brazilian Amazonia with contiguous campinarana and terrafirme forest areas. We aimed to assess the knowledge and perceptions of residents regarding the purpose of timber exploitation, focusing on species that they use intensively in both environments. At the same time, we analyzed forest inventories within the reserve to assess the current population status of timber species cited by residents, and to identify possible consequences of the logging activity.

\section{MATERIAL AND METHODS}

\section{Study area}

The study was undertaken in the Tupé Sustainable Development Reserve (Tupé SDR), a protected area located in the municipality of Manaus (Amazonas state), created in 2005 , that occupys 11,973 ha on the left margin of the Negro River, approximately $25 \mathrm{~km}$ west of the city of Manaus (Figure 1). The latest demographic survey in the reserve was carried out in 2007 and indicated 2508 inhabitants distributed in six communities (Chateaubriand et al. 2009). Some anthropogenic pressures that the SDR is experiencing are illegal hunting and fishing, uncontrolled tourism, lack of land property regularization and deforestation (SEMMAS 2017a; b).

Approximately $90 \%$ of the area of the Tupé SDR is covered by well drained, closed-canopy terra-firme forest (Scudeller et al. 2005). The remaining $10 \%$ of the area is covered by floodplain and white-sand forests (campinaranas). The former extends along the narrow riverine floodplains of black water rivers (igapó forest). Campinaranas are closed-canopy forests with clear stratification, distributed in small patches of extremely leached sandy soils within the terra-firme forest (Demarchi et al. 2018).

We interviewed residents from two communities located in the northeast of the reserve, on the right margin of the TarumãMirim River: Agrovila (02 $\left.58^{\prime} 02,98^{\prime \prime} \mathrm{S}, 60^{\circ} 12^{\prime} 34,49^{\prime \prime} \mathrm{W}\right)$ and Julião $\left(03^{\circ} 00^{\prime} 27.47^{\prime \prime S}, 60^{\circ} 12^{\prime} 14.97^{\prime \prime} \mathrm{W}\right)$ (Figure 1). The main access to the communities is by boat, and is impaired during the dry season by the low river level. According to local community leaders, in 2014 Agrovila had 110 permanent resident families, and Julião 80. Most community members engage in extractivist activities, such as hunting and fishing, 


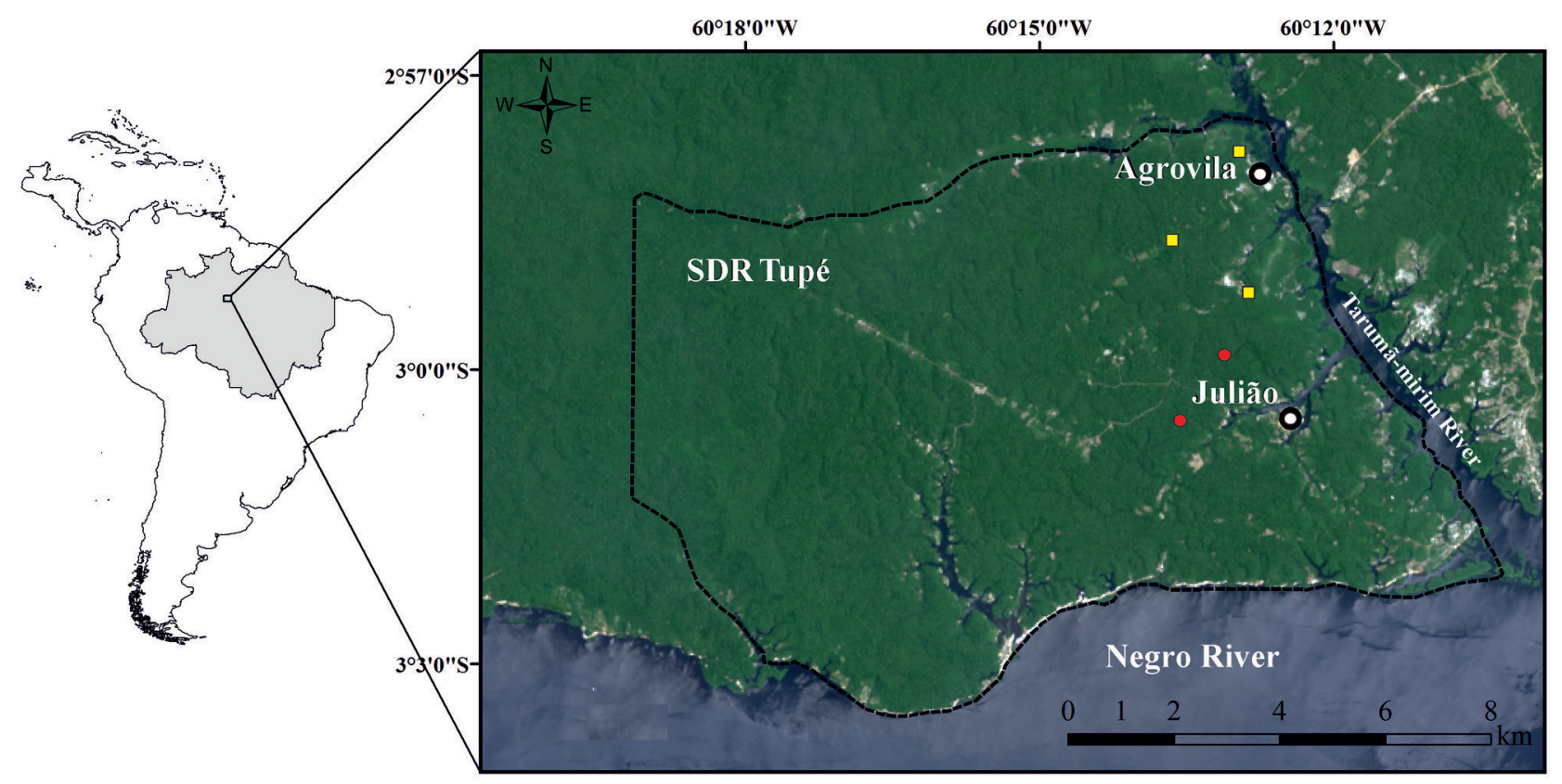

Figure 1. Image of the study area showing the limits of the Tupé Sustainable Development Reserve. The black circles indicate the two riverside communities sampled. Green areas represent vegetation with little or no human alteration; white areas are no longer covered by natural vegetation. Yellow squares represent the three campinarana inventory plots; red circles represent the two terra-firme inventory plots. The small map shows the location of the Tupé SDR within the shaded area of the Brazilian Amazon region. This figure is in color in the electronic version.

slash-and-burn agriculture, logging, and collection of nonwood forest products. Both communities are surrounded by campinarana and terra-firme forests.

The Ethics Committee on Human Research of Instituto Nacional de Pesquisas da Amazônia (CEP/INPA) approved this research (protocol number 213.634), and each interviewee signed a term of free, prior and informed consent prior to being questioned.

\section{Data analysis}

We interviewed a total of 51 residents, 35 from the Agrovila (13 were women and 22 were men) and 16 from the Juliáo (two were women and 14 were men) community. The difference in sample size between communities and between genders was due to that logging activity is more common in Agrovila, and is carried out mostly by men. To collect the information from the residents, we made monthly 4 to 6-day visits to the communities from April 2013 to January 2014. The interviews were always accompanied by the same community member. The selection criteria for the residents to participate in the interviews was a minimum five-year residence time in the community, being at least 16 years old, and a livelihood dependent on subsistence activities in the adjacent forest areas.

We used semi-structured interviews, following a script of questions that allowed the development of a more open conversation with the informant (Alexiades 1996). Free lists of exploited timber species were prepared from individual interviews. Informants were questioned about which timber species were common in the recent past (i.e. the last 10-20 years, during which the communities expanded, increasing the pressure on timber species), and which species were perceived as currently (1) disappearing locally; (2) being difficult to find; and (3) only being found by moving to distant places (Supplementary Material, Appendix S1). The questions focused only on timber species that were considered abundant in the recent past and are currently considered at risk, i.e. species that are in population decline in the areas that are intensively used by the residents. In addition to logging, we also asked for what other purposes the mentioned timber species were used. These species were attributed to timber and non-timber use categories based on the description of interviewees and other studies (Galeano 2000; Lawrence et al. 2005) (Supplementary Material, Appendix S2).

Using the data obtained with the free lists, we calculated the Cognitive Salience Index $(S)$ of each timber species (Sutrop 2001), combining the parameters: number of times the tree was mentioned $(\mathrm{F})$, average rank position of the tree on the lists $(\mathrm{mP})$ and total number of lists $(\mathrm{N})$, according to the formula:

$$
\mathrm{S}=\mathrm{F} /(\mathrm{N} \mathrm{mP})
$$


$S$ values can vary from 0 to 1 , where higher values indicate that greater importance is given to the item (Thompson and Juan 2006). Thus, the higher the $S$ value, the higher the pressure of use for the species. To calculate $S$ we considered only species that were mentioned more than once.

To identify possible consequences of the logging activity on the current population status of timber species, the values of $S$ were crossed with data from forest-inventory plots located less than $3 \mathrm{~km}$ from the central points of the communities. We used two 1-ha inventory plots in terrafirme forest which were surveyed in 2012 for trees with diameter at breast height $(\mathrm{DBH}) \geq 10 \mathrm{~cm}$ (Scudeller et al. unpublished data); and three 0.75 -ha plots in campinarana patches which were surveyed in 2014 for trees with $\mathrm{DBH} \geq$ $5 \mathrm{~cm}$ (Demarchi et al. 2018). We also assessed the population status of free-listed timber species (thus under pressure in the Tupé SDR according to our criteria) in the list of hyperdominant Amazonian tree species (ter Steege et al. 2013) which is based on 1,430 tree inventories distributed throughout the Amazon Basin.

Samples from the species mentioned by the informants were collected, pressed, dried and identified to species level by parataxonomists and by comparing the samples with the existing exsiccates in the herbarium of Instituto Nacional de Pesquisas da Amazônia (INPA). The samples were deposited in the INPA herbarium and the scientific names were standardized according to the Brazilian Flora Checklist (Flora do Brasil 2020), following the APG IV (2016) system.

\section{RESULTS}

Among the 51 interviewed residents (Table 1), 15 (29.4\%) reported practicing timber trade within Tupé SDR and recognized this activity as one of the main sources of family income, by exploiting timber according to the demand of buyers. The remaining $34(70.6 \%)$ residents reported exploring wood sporadically, according to their needs (Supplementary

Table 1. Age, residence time in the community and scholarity of 51 residents of two communities in the Tupé Sustainable Development Reserve, central Brazilian Amazonia. Values are the mean \pm standard deviation, followed by the minimum and maximum values in parentheses.

\begin{tabular}{lcc}
\hline & Agrovila & Julião \\
\hline Interviewed & 35 & 16 \\
\hline Age (years) & $44.2 \pm 14.7(18-80)$ & $54.4 \pm 14.9(33-80)$ \\
\hline Residence time (years) & $16.4 \pm 10.7(5-48)$ & $24 \pm 15.1(5-59)$ \\
\hline Scholarity (years) & $4.4 \pm 4.1(0-11)$ & $3.5 \pm 3.3(0-11)$ \\
\hline
\end{tabular}

Material, Figure S1). All 15 woodworkers reported that they regularly harvested trees near the community (around $500 \mathrm{~m}$ from the central point), but nowadays need to move much farther (from 3 to $5 \mathrm{~km}$ on average, depending on the species), even exploring areas outside the SDR.

A total of 26 timber species were mentioned in the interviews, 17 of which presented the minimum number of citations allowing for the $S$ calculation. The order in which the species are ranked according to the $S$ values indicates that a few are undergoing anthropic pressure (Table 2). The highest values were obtained for species from terra-firme forests, such as Mezilaurus itauba (Meisn.) Taub. ex Mez (itaúba) and Minquartia guianensis Aubl. (acariquara), and for species that occurred in both forest types, such as Scleronema micranthum (Ducke) Ducke (cedrinho) and Manilkara bidentata (A.DC.) A.Chev. (maçaranduba). On the other hand, the species that were restricted to campinarana, such as Aldina heterophylla Spruce ex Benth. (macucu) and Aniba santalodora Ducke (louro-limão), appear with the lowest $S$ values (Table 2).

Some of the mentioned timber species are identified with non-timber products, such as the Bertholletia excelsa Bonpl. (castanheira), which is important in the diet of traditional Amazonian populations, and is well valued in the local trade markets. Other species stand out because of their multiple uses, such as Hymenaea courbaril L. (jatobá), which has medicinal properties, and is used for prey attraction when hunting, and as food; and S. micranthum (cedrinho), which is used for handicraft, prey attraction when hunting, medicinal purposes, and others.

From the 17 timber species identified by interviewees, two popular names could not be associated with the botanic vouchers and their respective scientific names. In campinarana inventories, four timber species presented high relative densities of more than 15 individuals per hectare, of which three, Simarouba amara Aubl. (marupá), A. heterophylla (macucu) and A. santalodora (louro-limão), had the lowest $S$ values. In terra-firme, only one species, $S$. micranthum (cedrinho), appeared with high relative density, and had a high $S$ value (the second highest reported). The relative densities of all other terra-firme species were low, or they were not even recorded in the inventory plots, having high $S$ values, e.g. $M$. itauba (itaúba) and M. guianensis (acariquara).

Although most of the mentioned timber species had low relative density in the inventory plots, eight of them are considered hyperdominant according to ter Steege et al. (2013). Four of them, Brosimum rubescens Taub. (muirapiranga), M. itauba (itaúba), M. guianensis (acariquara) and B. excelsa (castanheira), occurr exclusively in terra-firme forests, and only one of them, A. heterophylla (macucu), occurs exclusively in campinarana. 
Table 2. List of the timber species that 51 residents of the Tupé Sustainable Development Reserve (central Brazilian Amazonia) mentioned as locally in decline, including the forest types in which each species predominantly occurs, and its timber and non-timber use categories according to interviewees. The relative density (RD) and number of individuals (Abun) of the species registered in terra-firme (TF) and white-sand or campinarana (CA) forest survey plots, as well as its ranking in the list of hyperdominant Amazonian species (HDR) are indicated. The Cognitive Salience Index (S) was calculated from free lists determined by the interviewees.

\begin{tabular}{|c|c|c|c|c|c|c|c|c|c|}
\hline Species & Family & Local popular name & Forest type & $\begin{array}{l}\text { Non-timber use } \\
\text { category }\end{array}$ & $\begin{array}{l}\text { Timber use } \\
\text { category }\end{array}$ & $\begin{array}{l}\text { RD (Abun) } \\
\text { TF }\end{array}$ & $\begin{array}{l}\mathrm{RD} \text { (Abun) } \\
\text { CA }\end{array}$ & HDR & S \\
\hline $\begin{array}{l}\text { Mezilaurus itauba (Meisn.) } \\
\text { Taub. ex Mez }\end{array}$ & Lauraceae & itaúba & TF & - & Con, Tec & 0 & 0 & 118 & 0.334 \\
\hline $\begin{array}{l}\text { Scleronema micranthum } \\
\text { (Ducke) Ducke }\end{array}$ & Malvaceae & cedrinho & $\mathrm{TF}, \mathrm{CA}$ & Han, Hun, Med, Oth & Con, Tec & $1.46(16)$ & $0.15(6)$ & 115 & 0.227 \\
\hline $\begin{array}{l}\text { Hymenolobium modestum } \\
\text { Ducke }\end{array}$ & Fabaceae & angelim & $\mathrm{TF}, \mathrm{CA}$ & Med & Con, Tec & 0 & $0.03(1)$ & - & 0.100 \\
\hline Minquartia guianensis Aubl. & Olacaceae & acariquara & TF & - & Con & $0.27(3)$ & 0 & 54 & 0.074 \\
\hline $\begin{array}{l}\text { Licaria chrysophylla (Meisn.) } \\
\text { Kosterm. }\end{array}$ & Lauraceae & louro-aritu & $\mathrm{TF}, \mathrm{CA}$ & - & Con, Tec & 0 & $0.03(1)$ & - & 0.072 \\
\hline $\begin{array}{l}\text { Sextonia rubra (Mez) van } \\
\text { derWerff }\end{array}$ & Lauraceae & louro-gamela & TF & - & Con, Tec & 0 & 0 & - & 0.060 \\
\hline Ocotea sp. & Lauraceae & louro-preto & TF & - & Con, Tec & - & - & - & 0.044 \\
\hline Pouteria sp. & Sapotaceae & abiurana & $\mathrm{TF}, \mathrm{CA}$ & Foo, Hun, Fis & Con & - & - & - & 0.029 \\
\hline Hymenaea courbaril L. & Fabaceae & jatobá & TF & Foo, Hun, Med & Con & $0.09(1)$ & 0 & - & 0.026 \\
\hline $\begin{array}{l}\text { Manilkara bidentata (A.DC.) } \\
\text { A.Chev. }\end{array}$ & Sapotaceae & $\begin{array}{l}\text { maçarandubal } \\
\text { maçaranduba-da- } \\
\text { campina }\end{array}$ & $\mathrm{TF}, \mathrm{CA}$ & Foo, Hun, Oth & Fir, Con, Tec & $0.18(2)$ & $3.26(129)$ & 131 & 0.025 \\
\hline Bertholletia excelsa Bonpl. & Lecythidaceae & castanha/castanheira & TF & Foo & Con & 0 & 0 & 187 & 0.022 \\
\hline $\begin{array}{l}\text { Buchenavia macrophylla } \\
\text { Eichler }\end{array}$ & Combretaceae & $\begin{array}{c}\text { tanimbuca-verda- } \\
\text { deira }\end{array}$ & $\mathrm{TF}, \mathrm{CA}$ & - & Con, Tec & 0 & $0.1(4)$ & - & 0.019 \\
\hline Brosimum rubescens Taub. & Moraceae & $\begin{array}{l}\text { muirapiranga/falso- } \\
\text { pau-brasil }\end{array}$ & TF & Med & Con, Tec & $0.18(2)$ & 0 & 46 & 0.019 \\
\hline Andira micrantha Ducke & Fabaceae & sucupira & $\mathrm{TF}, \mathrm{CA}$ & Med & Con & 0 & $0.08(3)$ & - & 0.010 \\
\hline Simarouba amara Aubl. & Simaroubaceae & marupá & $T F, C A$ & Med & Con, Fir, Tec & $0.09(1)$ & $1.21(48)$ & 108 & 0.010 \\
\hline $\begin{array}{l}\text { Aldina heterophylla Spruce } \\
\text { ex Benth. }\end{array}$ & Fabaceae & $\begin{array}{c}\text { macucu/macucu-da- } \\
\text { campina/macucu- } \\
\text { de-sangue }\end{array}$ & CA & Fis, Han, Hun, Oth & Con, Tec & 0 & $4.3(170)$ & 227 & 0.006 \\
\hline Aniba santalodora Ducke & Lauraceae & louro-limão & $C A$ & - & Con, Tec & 0 & $0.81(32)$ & - & 0.005 \\
\hline
\end{tabular}

$\mathrm{S}=$ Cognitive Salience Index for the species the residents considered to be locally disappearing; RD (Abun) TF = relative density and (in parenthesis) the total number of individuals recorded in two inventories totalizing 2 ha in terra-firme forests (Scudeller et al., unpublished data); RD (Abun) $C A=$ relative density and (in parenthesis) the total number of individuals recorded in three inventories totalizing 2.25 ha in campinarana forests (Demarchi et al. 2018); HDR= position in the list of the 227 species considered as hyperdominant in the Amazon Basin (ter Steege et al. 2013); Con = construction; Fir = firewood; Fis = fishery; Foo = food; Han = handicrafts; Hun = hunting attractant; Med = medicinal; Oth = Others; Tec = technology. Definition of each category in the Supplementary Material, Appendix S2.

\section{DISCUSSION}

\section{Resident perception on timber species}

The species with high $S$ values, M. itauba (itaúba), $S$. micranthum (cedrinho) and Hymenolobium modestum Ducke (angelim), are valued locally, specially for their wood durability and aesthetic beauty. Therefore, many residents claimed it is rare to find large individuals of these species in the local forests. The results derived from the interviews suggest a replacement process of some species that are apparently declining in the surrounding terra-firme forests with species from campinarana, such as $A$. heterophylla (macucu). As this replacement seems to have initiated recently, campinarana species still present low $S$ values and high population densities. The following statements by two residents illustrate these perceptions:

"Macucu is only being used because we don't see cedrinhos, large maçarandubas and louro-aritu anymore" (60 years old, resident in Agrovila for 36 years).
"In the old days, there was a lot of itaúba that even formed clusters; nowadays we don't see them anymore, so people have to use other wood with less quality" (62 years old, resident in Julião for 50 years).

The reports from residents about the current difficulty to find timber species that were considered abundant in the recent past suggests some of these species may be over-exploited and are possibly undergoing population reduction within the reserve. Species that have high $S$ values should be prioritized in studies of population dynamics, to produce accurate exploitation data and guarantee the sustainable use of resources.

The impact of removing individuals and species from plant communities, and its consequences for human populations, who depend on the extraction of forest resources, is poorly documented for Amazonia (Macedo and Anderson, 1993; Veríssimo et al. 1995). For example, A. heterophylla (macucu) is one of the most exploited timber species in campinarana, and 
is also one of the ecologically most important species in these forests (Anderson, 1981; Targhetta et al. 2015; Demarchi et al. 2018), as it is one of the few species that reach similar basal area to species from terra-firme forests (Stropp et al. 2011). Additionally, A. heterophylla in campinarana has important roles in the nitrogen fixation process (Mardegan et al. 2009), as a substrate for the epiphytic community (Marí et al. 2016), and as a facilitator of colonization by other species under its shade, as its canopy width can reach up to two times its height (Anderson et al. 1975).

The interviewees mentioned many non-timber uses for the listed timber species, specially for nutrition and medicinal purposes. The trade of non-timber forest products represents an important source of income for many families in the Amazon (Ticktin 2004). In a Sustainable Development Reserve, this activity may represent a sustainable alternative to the timber trade, as it does not involve tree logging. In this way, when logging is very intense, it puts at risk a number of other income-generating possibilities that are less damaging to the integrity of the forest.

\section{Differences in logging by forest type}

The plot inventories indicated that, in campinaranas, there are timber species that still have high relative densities. However, the low $S$ values for these species suggests that their use by the residents is recent. In contrast, in terra-firme plots, only one species (S. micranthum) had high relative density, while all other species were recorded with one to three individuals, or were not recorded at all. Differences in abundance of timber species between both forest types can influence logging activities, because the residents need to extract much more trees in campinarana than in terra-firme forest to obtain the same amount of wood. However, some timber species in campinarana are very abundant, and often occur in aggregated patches, which likely explains why the residents have begun to exploit these forests.

The campinarana species richness and vegetation size are much lower than in terra-firme forests (Stropp et al. 2011), resulting in different logging impacts in each forest type. Although most terra-firme species occur in naturally low population densities, the range of exploited species in terrafirme forests is greater than in campinarana, where only a few species have large basal areas with timber potential, such as M. bidentata (maçaranduba) and A. heterophylla (macucu). These species can be the most abundant in campinarana plant communities (Targhetta et al. 2015; Demarchi et al. 2018).

Exploiting species according to their abundance can reduce the risks of extinguishing rare species (Tacher 2002), but can threaten local abundant species. Therefore, the exploitation of abundant species requires management guidelines, considering that the impacts of logging activities may vary depending on the species exploited (Scabin $e$ t al. 2011). This is particularly important in campinaranas, where the low productivity, low resilience and low woody growth rate (Adeney et al. 2016) demand caution and better knowledge to enable sustainable exploitation, and to prevent long-term exploitation from endangering the demography and growth of these species.

Although most terra-firme species mentioned as endangered by the residents had low local densities, seven of them were considered hyperdominant in the Amazon basin (ter Steege et al. 2013), which may have three possible explanations: (1) some terra-firme species considered generally hyperdominant in the Amazon basin naturally occur in low densities in the Tupé SDR; (2) the number and/or location of our inventory plots was not adequate to capture the occurrence pattern of these species in the SDR; or (3) the low density of these species in the Tupé SDR resulted from over-exploitation in areas close to human settlements.

\section{Implications for management policies}

One of the main objectives of an SDR is to conserve natural ecosystems in consonance with the livelihood of traditional populations. Therefore natural resource exploitation must be carried out according to a management plan that considers potential sources and their specificities in different environments, as well as the demands and needs of local communities (Brasil 2000), in order to maintain the ecosystem under sustainable use (Fearnside 1989). The management plan of the Tupé SDR, which was approved only in 2017, is ambiguous about the circumstances in which logging activities are allowed, and this inaccuracy may be the main driver of the over-exploitation perceptions by the residents. Since about $30 \%$ of the interviewees are engaged in logging activities, a review of the management plan is recommended, to clarify restrictions and circumstances for logging, considering the ecological differences between terra-firme forests and campinarana. This is even more important considering that three of the species being exploited, A. santalodora (lourolimão), B. excelsa (castanheira) and M. itauba (itaúba), are included in the red list of Brazilian flora (Martinelli and Moraes 2013).

In this context, we recommend that a management plan for SDRs should consider: (1) to encourage the exploitation and trade chains of non-timber forest products and the development of other activities (such as tourism) as an income alternative for local residents, in consonance with forest conservation; (2) the incorporation of the traditional knowledge of local residents, and their perceptions on resource depletion, into decision-making processes; (3) the development of a logging plan that takes into account the use of publicly available data sets on standardized monitoring in long-term forest plots to access the life cycle and phenology of timber species; and (4) the integration of data from forest inventory studies and forest management techniques with ecological studies, such as successional dynamics, dispersal 
and predation processes; and studies that assess the genetic diversity and population bottlenecks of timber species.

\section{CONCLUSIONS}

In the Tupé Sustainable Development Reserve, in central Brazilian Amazonia, the perception of residents proved to be a useful tool to identify timber species under intensive logging. The residents' reports suggest that the most impacted terrafirme timber species are being replaced by local white-sand forest (campinarana) species. Yet only further monitoring and an assessment of the amount of timber used by the residents over time could confirm the magnitude of this process. In this study, we highlight the importance of considering the experience and perceptions of local residents, as well as of integrating traditional and scientific knowledge, to implement better environmental management strategies. This process of timber resource exploitation is not particular to the Tupé SDR and, therefore, the evaluation of its impacts and the implementation of management strategies to contain it should also be addressed in other Amazonian regions.

\section{ACKNOWLEDGMENTS}

We thank the Coordenaçáo de Aperfeiçoamento de Pessoal de Nível Superior - CAPES for scholarships to LOD and AL; Fundação de Amparo à Pesquisa do Estado do Amazonas FAPEAM (public call \# 021/2011); Conselho Nacional de Desenvolvimento Científico e Tecnológico - CNPq/PELDMAUA (grant \# 403792/2012-6 and \# 441590/2016-0) and Project Adaptação da Biota Aquática da Amazônia - ADAPTA (CNPq/FAPEAM/INPA) for financing the research; the residents of Tupé SDR for their welcoming and hospitality; the technicians of the MAUA/INPA group for technical support; the parataxonomists Antônio Mello and José Ferreira Ramos for helping with the botanical identifications; Maria Julia Ferreira and Gildo Feitoza for editing the figures; and three anonymous reviewers for their comments on previous versions of this manuscript.

\section{REFERENCES}

Adeney, J.M.; Christensen, N.L.; Vicentini, A.; Cohn-Haft, M. 2016. White-sand ecosystems in Amazonia. Biotropica, 48: 7-23.

Alexiades, M.N. 1996. Collecting ethnobotanical data: an introduction to basic concepts and techniques. In: Alexiades, M.N. (Ed.). Guidelines for ethnobotanical field collectors. The New York Botanical Garden, New York, p.53-94.

Anderson, A.B.; Prance, G.T.; Albuquerque, B.W.P. 1975. Estudos sobre as vegetações de Campinas Amazônica III: a vegetação lenhosa da Campina da Reserva Biológica INPA-SUFRAMA (Manaus-Caracaraí, km 62). Acta Amazonica, 5: 225-246.

Anderson, A.B. 1981. White-sand vegetation of Brazilian Amazonia. Biotropica, 13: 199-210.
APG IV. 2016. An update of the Angiosperm Phylogeny Group classification for the orders and families of flowering plants: APG IV. Botanical Journal of the Linnean Society, 181: 1-20.

Asner, G.P.; Knapp, D.E.; Broadbent, E.N.; Oliveira, P.J.C.; Keller, M.; Silva, J.N. 2005. Selective logging in the Brazilian Amazon. Science, 310: 480-482.

Berkes, F.; Colding, J.; Folke, C. 2000. Rediscovery of traditional ecological knowledge as adaptative management. Ecological Applications, 10: 1251-1262.

Berkes, F. 2004. Rethinking community-based conservation. Conservation Biology, 18: 621-630.

Brasil. 2000. Lei nr. 9.985, de 18 de julho de 2000. Institui o Sistema Nacional de Unidades de Conservação da natureza. Senado Federal. (http:// www.planalto.gov.br). Accessed on 15 Apr 2018.

Chateaubriand, A.D.; Andrade, E.B.; Parente, R.C.P.; Rayol, K.C.C. 2009. Reserva de Desenvolvimento Sustentável do Tupé-REDES do Tupé: espacialização e informação das comunidades. Manaus. Editora da Universidade Federal do Amazonas, Manaus, Brazil. 264p.

Daly, D.C.; Silveira, M.; Medeiros, H.; Castro, W.; Obermüller, F.A. 2016. The white-sand vegetation of Acre, Brazil. Biotropica, 48: 81-89.

Demarchi, L.O. 2014. Composição, conhecimento e uso de plantas de Campinarana por moradores da Reserva de Desenvolvimento Sustentável do Tupé - Amazônia Central. Master's dissertation, Instituto Nacional de Pesquisas da Amazônia, Brazil, 110p. (-http://localhost:8080/tede/handle/tede/1526). Accessed on 14 Jul 2018.

Demarchi, L.O.; Scudeller, V.V.; Moura, L.C.; Dias-Terceiro, R.G.; Lopes, A.; Wittmann, F.; Piedade, M.T.F. 2018. Floristic composition, structure and soil-vegetation relations in three white-sand soil patches in central Amazonia. Acta Amazonica, 48: 46-56

Fearnside, P.M. 1989. Extractive reserves in Brazilian Amazonia: an opportunity to maintain tropical rain forest under sustainable use. BioScience, 39: 387-393.

Ferreira, L.V.; Chaves, P.P.; Cunha, D.A.; Rosário, A.S.; Parolin, P. 2013. A extração ilegal de areia como causa do desaparecimento de Campinas e Campinaranas no estado do Pará, Brasil. Pesquisas, Botânica, 64: 157-173.

Fine, P.V.A.; García-Villacorta, R.; Pitman, N.C.A.; Mesones, I.; Kembel, S.W. 2010. A floristic study of the white-sand forests of Peru. Annals of the Missouri Botanical Garden, 97: 283-305.

Flora do Brasil 2020 em construção. Jardim Botânico do Rio de Janeiro. (http://floradobrasil.jbrj.gov.br/). Accessed on $30 \mathrm{Feb}$ 2018.

Fortini, L.B.; Zarin, D.J. 2011. Population dynamics and management of Amazon tidal floodplain forests: Links to the past, present and future. Forest Ecology and Management, 261: 551-561.

Galeano, G. 2000. Forest use at the Pacific coast of Chocó, Colômbia: a quantitative approach. Economic Botany, 54: 358-376.

Guevara, J.E.; Damasco, G.; Baraloto, C.; Fine, P.V.A.; Peñuela, M.C.; Castilho, C. et al. 2016. Low phylogenetic beta diversity 
and geographic neo-endemism in Amazonian white-sand forests. Biotropica, 48: 34-46.

Lawrence, A.; Phillips, O.L.; Ismodes, A.R.; Lopez, M.; Rose, S.; Wood, D.; Farfan, A.J. 2005. Local values for harvested forest plants in Madre de Dios, Peru: towards a more contextualised interpretation of quantitative ethnobotanical data. Biodiversity and Conservation, 14: 45-79.

Luizão, F.J.; Luizão, R.C.C.; Proctor, J. 2007. Soil acidity and nutrient deficiency in central Amazonian heath forest soils. Plant Ecology, 192: 209-224.

Macedo, D.S.; Anderson, A.B. 1993. Early ecological changes associated with logging in an Amazon floodplain. Biotropica, 25: 151-163.

Marí, M.L.G.; Toledo, J.J.; Nascimento, H.E.M.; Zartman, C.E. 2016. Regional and fine scale variation of holoepiphyte community structure in central Amazonian white-sand forests. Biotropica, 48: 70-80.

Mardegan, S.F.; Nardoto, G.B.; Higuchi, N.; Moreira, M.Z.; Martinelli, L.A. 2009. Nitrogen availability patterns in whitesand vegetations of Central Brazilian Amazon. Trees, 23: 479488.

Martinelli, G.; Moraes, M.A. 2013. Livro vermelho da flora do Brasil. Instituto de Pesquisas Jardim Botânico do Rio de Janeiro, Rio de Janeiro, 1100p.

Scabin, A.B.; Costa, F.R.C.; Schöngart, J. 2011. The spatial distribution of illegal logging in the Anavilhanas archipelago (Central Amazonia) and logging impacts on species. Environmental Conservation, 39: 111-121.

SEMMAS 2017a. Plano de gestão. Reserva de Desenvolvimento Sustentável do Tupé. Volume I - Diagnóstico. Terra Consultoria Ambiental, Manaus, Brazil, 199p.

SEMMAS 2017b. Plano de gestão. Reserva de Desenvolvimento Sustentável do Tupé. Volume II-Planejamento. Terra Consultoria Ambiental, Manaus, Brazil, 58p.

Scudeller, V.V.; Aprile, F.M.; Melo, S.; Santos-Silva, E.N. 2005. Reserva de Desenvolvimento Sustentável do Tupé: características gerais. In: Santos-Silva, E.N.; Aprile, F.M.; Scudeller, V.V.; Melo, S. (Ed.). Biotupé: Meio fisico, diversidade biológica e sociocultural do Baixo Rio Negro, Amazônia Central. Editora INPA, Manaus, Brazil, p.xi-xxi.
Stropp, J.; Van Der Sleen, P.; Assunção, P.A.; Silva, A.L.; ter Steege, H. 2011. Tree communities of white-sand and terra-firme forests of the upper Rio Negro. Acta Amazonica, 41: 521-544.

Sutrop, U. 2001. List Task and a Cognitive Salience Index. Field Methods, 13: 263-276.

Tacher, S.I.L.; Rivera, R.A.; Romero, M.M.M.; Fernández, A.D. 2002. Caracterización del uso tradicional de La flora espontânea em La comunidad Lacandona da Lacanhá, Chiapas, México. Interciencia, 27: 512-520.

Targhetta, N.; Kesselmeier, J.; Wittmann, F. 2015. Effects of the hydroedaphic gradient on tree species composition and aboveground wood biomass of oligotrophic forest ecosystems in the central Amazon basin. Folia Geobotanica, 50: 185-205.

ter Steege, H.; Pitman, N.C.A.; Sabatier, D.; Baraloto, C.; Salomão, R.P.; Guevara, J.E.; et al. 2013. Hyperdominance in the Amazonian tree flora. Science, 342: 325-336.

Thompson, E.C.; Juan, Z. 2006. Comparative cultural salience: measures using free-list data. Field Methods, 18: 398-412.

Ticktin, T. 2004. The ecological implications of harvesting nontimber forest products. Journal of Applied Ecology, 41: 11-21.

Veríssimo, A.; Barreto, P.; Mattos, M.; Tarifa, R.; Uhl, C. 1992. Logging impacts and prospects for sustainable forest management in an old Amazonian frontier: The case of Paragominas. Forest Ecology and Management, 55: 169-199.

Veríssimo, A.; Barreto, P.; Tarifa, R.; Uhl, C. 1995. Extraction of a high-value natural resource in Amazonia: the case of mahogany. Forest Ecology and Management, 72: 39-60.

Wittmann, F.; Wittmann, A.O. 2010. Use of Amazonian Floodplain Trees. In: Junk, W.J.; Piedade, M.T.F.; Wittmann, F.; Schöngart, J.; Parolin, P. (Ed.). Amazonian Floodplain Forests. Ecophysiology, Biodversity and Sustainable Management. Springer, Ecological Studies, Dordrecht, Heidelberg, London, New York, p.389-418.

RECEIVED: $14 / 06 / 2019$

ACCEPTED: $12 / 08 / 2019$

ASSOCIATE EDITOR: Francesco Ripullone 
SUPPLEMENTARY MATERIAL (only available in the electronic version)

DEMARCHI et al. Logging impact on Amazonian white-sand forests: perspectives from a sustainable development reserve

Appendix S1. Script of the questionaire used to interview residents of two communities in Tupé Sustainable Development Reserve (central Brazilian Amazonia) for collection of data on timber exploitation.

\section{Semi-structured interview}

1) Full name (or nickname):

2) Age:

3) Gender:

4) Profession / occupation:

5) Education (years in school):

6) Time living in the community:

7) Origin:

8) Were you born in this community? If no, how many years ago did you move to this community?

9) Do you make wood trade? If yes, where?

10) How far do you usually go to explore wood currently / in the recent past?

\section{Free lists}

1) Cite the timber trees that used to be abundant and now are difficult to find in the forest:

2) Which timber trees do you need to move ever farther to find?

\section{Details for each timber species}

1) Do you usually commercialize the timber from this tree?

2) What other uses does this tree have?
Appendix S2. Definition of use categories for timber species based on the types of uses mentioned in interviews by 51 residents of Tupé Sustainable Development Reserve (central Brazilian Amazonia).

\begin{tabular}{ll}
\hline & Types of uses mentioned \\
\hline Construction & $\begin{array}{l}\text { Wood for construction in general, including fences and } \\
\text { lighting poles }\end{array}$ \\
\hline Technology & $\begin{array}{l}\text { Wood for small and specific objects and tools, such as bow } \\
\text { and arrows, spear, barbecue stick, hoe cord and ax, fishing } \\
\text { pole, shotgun butt, clog, musical instrument }\end{array}$ \\
\hline Food & $\begin{array}{l}\text { Fruits and seeds in natura, or used to make juices, cakes, } \\
\text { jellies and bread }\end{array}$ \\
\hline Handicrafts & $\begin{array}{l}\text { Seeds used for making necklaces; binding and braiding } \\
\text { fibers; resin used to dye fabric }\end{array}$ \\
\hline Firewood & $\begin{array}{l}\text { Trunk and twigs for making firewood and coal; bark to light } \\
\text { fire }\end{array}$ \\
\hline Medicinal & $\begin{array}{l}\text { Bark, root and resin used as tea or bath to treat a wide } \\
\text { variety of diseases }\end{array}$ \\
\hline Fishery & $\begin{array}{l}\text { Fruit used as fish bait; caterpillar that feeds on the plant } \\
\text { used as fish bait }\end{array}$ \\
\hline Hunting & $\begin{array}{l}\text { Fruit still on the tree or on the ground, which attract } \\
\text { animals for the hunting activity }\end{array}$ \\
\hline attractant & $\begin{array}{l}\text { Resin to dye various objects; latex to mix with rubber; wood } \\
\text { dust for fertilizer }\end{array}$ \\
\hline Others
\end{tabular}

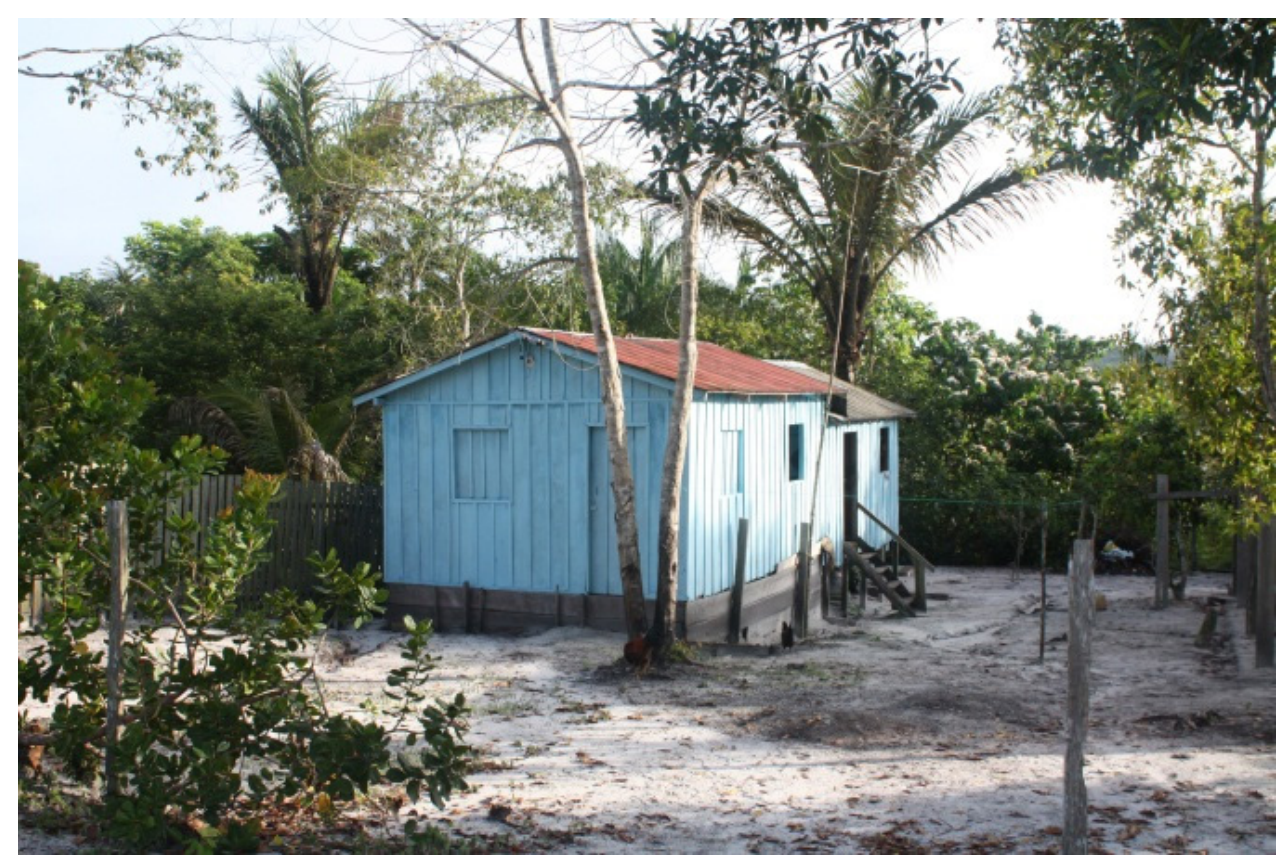

Figure S1. A wooden house typical of the communities within the Tupé Sustainable Development Reserve (central Brazilian Amazonia), built from wood taken from the surrounding forests. This example was photographed in the Agrovila community, established on sandy soil in campinarana forest. Credit: Layon Oreste Demarchi. 